\title{
EU LAW AND GENDER-BALANCED BOARDS: MAKING EQUALITY EFFECTIVE
}

\author{
Snježana Vasiljević* and Ana-Maria Sunko**
}

\begin{abstract}
Summary: This paper reflects on the problem of gender balance in economic decision-making, considers its legislative roots, and offers potential guidance for its solution. The paper takes into account the origin of positive action and effective equality in the scope of EU legislation and CJEU case law and tackles the most troublesome issues regarding the new initiative of making equality in boards effective. It analyses gender equality in three approaches of positive action. Firstly, the fragile approach at the EU level, despite the rich historical impact it has had. Secondly, positive action on CJEU terrain where standards of equality have been set by useful case law. Finally, the form of legislative positive action which aimed to break the glass ceiling in corporate boards - the 'Women on Boards Directive'. With such an approach, the paper offers the authors' view on the stability of positive action and an interpretation of the above-mentioned directive.
\end{abstract}

\section{Introduction}

At the level of the EU there has been a rich history of regulating gender equality issues since 1957, which means that the EU has been working on promoting gender equality for 60 years. Thus, the EU sets an example for the affirmation of equal opportunities for all governing relations between men and women. Promoting gender equality is a core activity of the EU: equality between women and men is a fundamental EU value (article 2 TEU), an EU objective (article 3 TEU) and a driver of economic growth. ${ }^{1}$ At the beginning, EU equality legislation focused only on labour relations. There was no gender equality legislation outside the workplace. Over the years, the EU has developed an advanced equality framework, but the issue of economic decision-making has remained unmentioned.

The purpose of this paper is to show that despite rich gender equality legislation and the case law of the Court of Justice of the European

Assistant Professor at the Department of European Public Law, Faculty of Law, University of Zagreb, snjezana.vasiljevic@pravo.hr.

** Graduate at the Faculty of Law, University of Zagreb, anamaria.sunko@gmail.com.

1 Commission, Communication to the European Parliament, the Council, the European Economic and Social Committee and the Committee of the Regions 'Strategy for equality between women and men 2010-2015' COM (2010) 491 final. 
Union (CJEU) on positive action in the framework of gender equality, in the current EU legal framework there is a lack of legislative measures necessary to improve the position of women in decision-making. The authors analyse the scope of EU gender equality legislation and case law on positive action and suggest that the proposed directive on improving the gender balance among non-executive directors of companies (the Women on Boards Directive) fulfils the requirements of the CJEU's case law on positive action and should be adopted in order to achieve genderbalanced boards.

The second part of the paper deals with the EU's perspective on 'fragile' positive action which will show that the EU has created rich primary and secondary gender equality law. Over the years, the European Union has produced several non-binding measures aimed at improving the participation of women in decision-making. ${ }^{2}$ However, these (nonbinding) recommendations have not led to any palpable progress. Obligatory, or binding, legislation is also unsuitable and does not cover all the areas of interest in the field of gender balance.

The third part of the paper discusses positive action on the CJEU's terrain. A significant role in gender equality has been played by the Court. During its long work and rich legal history and guidance, the CJEU has made a legal basis in the sphere of case law for women in economic decision-making. The CJEU case law on positive action is limited to gender and draws its legal basis from the first equality Directive 76/207/EEC. The CJEU 'has established criteria that need to be met in order to reconcile the two concepts of formal equality of treatment and positive action aimed at bringing about de facto equality (by promoting the under-represented sex)'. ${ }^{3}$ How far the national courts have actually implemented the 'guidelines' put in practice by the CJEU is an area that has generally been inadequately investigated.

Moreover, because of the constant problem of gender inequality in economic decision-making (the number of women drops at every stage of executive careers ${ }^{4}$ despite the fact that $60 \%$ of graduates are female ${ }^{5}$ ) and given the lack of legislation to regulate this issue, the authors claim that a

\footnotetext{
2 Such as: Commission (n 1).

3 Commission, 'Women on Boards - Factsheet 3: Legal Aspects' < http://ec.europa.eu/ justice/gender-equality/files/womenonboards/factsheet-general-3_en.pdf> accessed 3 January 2018.

4 R Hosie, 'Women Are Better Leaders Than Men, Study of 3,000 Managers Concludes' Independent, (London, 30 March 2017) < www.independent.co.uk/life-style/women-better-leaders-men-study-a7658781.html?utm_content=buffera0161\&utm_medium=social\&utm_ source=twitter.com\&utm_campaign=buffer $>$ accessed 3 January 2018.

5 Commission, 'Gender Balance on Corporate Boards: Europe Is Cracking the Glass Ceiling' (Fact Sheet, July 2016) <http:/ / ec.europa.eu/justice/gender-equality/files/womenonboards/factsheet_women_on_boards_web_2015-10_en.pdf> accessed 3 January 2018.
} 
directive on improving the gender balance among non-executive directors of companies listed on stock exchanges and related measures is highly needed. The purpose of the proposal for such a directive was very appropriate to ensure an equal number of women on boards. Its target was to set a quota of $40 \%$ of women on boards in publicly listed companies. This was a way of breaking the glass ceiling and the circle of man power at the top of decision-making. However, because the Member States were not able to reach an agreement, the proposal did not come to life. The proposal had set goals and procedural obligations for Member States which could have led to goals promoted in its scope. Nevertheless, the proposal is often criticised for sanctions which were not rigorous enough to actually ensure gender-balanced boards. 'It does not impose an obligation to guarantee a certain result, but an obligation to put in one's best efforts to take the necessary measures that can contribute to achieving the objective. ${ }^{6}$ Other questions which arise here concern soft and hard law as a positive instrument, and where precisely the directive stands in this sense. Can the directive be considered as hard law given its really weak obligations? By analysing the substantive target and subject of the proposal, one must ask if it goes far enough and why it merely mentions non-executive boards. Finally, after tackling all these questions, the authors can answer the most important one, which is the way the proposal for the directive fulfils the requirements of the CJEU case law on positive action, or whether it even has to fulfil them.

This paper shows that the proposal for the directive combines the requirements of the CJEU case law on positive action and that it should be adopted in order to achieve gender-balanced boards.

\section{The EU 'perspective' for 'fragile' positive action}

The term 'positive measures' (or positive action) refers to action aimed at favouring access by members of certain categories of people, in this particular case, women, to rights which they are guaranteed, to the same extent as members of other categories, in this particular case, men. ${ }^{7}$ 'Nevertheless, confusion often surrounds exactly what type of measures fall under the concept of positive action.' ${ }^{8}$ There are several

6 LAJ Senden and M Visser, 'Balancing a Tightrope: The EU Directive on Improving the Gender Balance among Non-executive Directors of Boards of Listed Companies' (2013) 1 European Gender Equality Law Review < http://dspace.library.uu.nl/bitstream/handle/1874/287052/Senden+-+Balancing+a+Tightrope+-+The+EU+Directive. pdf?sequence $=1>$ accessed 3 January 2018 .

7 Council of Europe, 'Positive Action in the Field of Equality between Women and Men' (Final Report of the Group of Specialists on Positive Action between Women and Men, EG-SPA 2000).

8 L Waddington and M Bell, 'Exploring the Boundaries of Positive Action under EU Law: A Search for Conceptual Clarity (2011) 48(5) CML Rev 1503. 
types of measures which are considered positive action, and they are: antidiscrimination support measures, outreach measures, redefining merit, indirect and direct preferences. ${ }^{9}$ Positive action falls within the scope of EU competences because of the Treaties and their strong support in this regard. For example, article 2 TEU considers sex equality as one of the social values of fundamental importance common to all Member States. ${ }^{10}$ Further, article 3 says that the EU must work against social exclusion and discrimination to promote equality between sexes within its market. In the scope of the TFEU, article 8 gives explicit instructions to the Union to act in a way which will eliminate inequalities and promote equality between men and women. ${ }^{11}$ Article 10 provides that the EU will implement policies and activities in order to defeat discrimination based on sex. Finally, article 157(3) TFEU, which is a basis of EU competence to deal with gender equality issues, was the strongest support for EU competence in the scope of positive action. This article explicitly provides the EU with the power to enact legislative measures to achieve equal opportunities and equal treatment of both sexes in matters of employment:

The European Parliament and the Council, acting in accordance with the ordinary legislative procedure, and after consulting the Economic and Social Committee, shall adopt measures to ensure the application of the principle of equal opportunities and equal treatment of men and women in matters of employment and occupation, including the principle of equal pay for equal work or work of equal value.

Consequently, this article was considered part of the legal background for the Proposal for a Directive of the European Parliament and of the Council on improving the gender balance among non-executive directors of companies listed on stock exchanges and related measures. ${ }^{12}$

A great majority of EU Member States regulate positive action in their equality/antidiscrimination legislation (Belgium, Bulgaria, Cyprus, Croatia, Czech Republic, Estonia, Germany Ireland, Island, Italy, Liechtenstein, Luxembourg, Macedonia, the Netherlands, Poland, Rumania, Slovenia, UK). Some of them, such as France, regulate positive action in their labour code. ${ }^{13}$

\footnotetext{
9 C McCrudden, 'Rethinking Positive Action' (1986) 15(1) Industrial Law Journal.

10 Treaty on European Union [2012] OJ C326/13.

11 Treaty on the Functioning of the European Union [2012] OJ C326/1.

12 Commission, Proposal for a Directive of the European Parliament and of the Council on improving the gender balance among non-executive directors of companies listed on stock exchanges and related measures COM (2012) 0614 final - (2012) 0299 (COD).

13 G Selanec and L Senden, 'Positive Action Measures to Ensure Full Equality in Practice between Men and Women including on Company Boards (European Commission, European Network of Legal Experts in the Field of Gender Equality, 2011) 16.
} 
Many of these States were clearly influenced by the UN Convention on the Elimination of all Forms of Violence against Women (CEDAW). States have a negative obligation to refrain from inequality and a positive obligation to promote de facto equality. Article 4(1) CEDAW explicitly provides that the adoption of temporary special measures aimed at accelerating de facto equality between men and women should not been considered discrimination. Article 4(1) does not in itself impose a duty on States to adopt and apply temporary special measures. Rather, it makes clear that if a State does take such measures, and if these measures fall within the terms of this provision, there can (by definition) be no complaint of discrimination. Thus, article 4(1) is an application instead of an exception to the definition of discrimination. Temporary special measures aim to remedy the effects of past or present discrimination against women and offer equal starting points or equal opportunities for women to $a c$ celerate the process of equal participation of women in all fields of social, economic, political and cultural life and/or the process of redistribution of power and resources and the bringing about of social and cultural change that will improve the de facto position of women and to neutralise the advantages that men have in the existing social, economic, political and cultural systems. ${ }^{14}$

However, the EU is one of the major actors in promoting gender equality. European primary and secondary law promotes principles of equality and non-discrimination. The origins of the EU women's policy lie in article 119 of the Treaty of Rome. Adopted in 1957, this article obliges Member States 'to ensure the application of the principle of equal pay for equal work'. ${ }^{15}$ In an analysis of European provisions and definitions on positive action it is necessary to mention that the Treaty of Amsterdam explicitly includes equality between women and men among the objectives of the EU. 'Positive action' was defined in 1976 in the context of British race relations, and was recommended in 1984 by the Council of Ministers of the then European Communities for improving the occupational position of women throughout the EC. Then it was incorporated into the Treaty of Amsterdam and into the directives of 2000. ${ }^{16}$ The adoption of article 13 is a reflection of the growing recognition of the need to develop a coherent and integrated approach to combating discrimination.

${ }_{14}$ I Boerefijn and others (eds), Temporary Special Measures: Accelerating de facto Equality of Women under Article 4(1) UN Convention on the Elimination of All Forms of Discrimination against Women (Intersentia 2003) 216.

15 C Hoskyns, 'The European Union and the Women Within: An Overview of Women's Rights Policy' in RA Elman (ed), Sexual Politics and the European Union: The New Feminist Challenge (Berghahn Books 1996) 14.

16 Directive 2000/43/EC of 29 June 2000 implementing the principle of equal treatment between persons irrespective of racial or ethnic origin [2000] OJ L180/22; Council Directive $2000 / 78 /$ EC of 27 November 2000 establishing a general framework for equal treatment in employment and occupation [2000] OJ L303/16. 
It allows for common legal and political approaches that include various bases, and also includes a unique definition of discrimination. This late development of general anti-discrimination legislation and the late implementation of the directives in the Member States led to the lack of antidiscrimination cases on discrimination on grounds other than sex before both national courts and the CJEU. In the mid-1990s consensus was reached to regulate other forms of discrimination in the European Union. The Amsterdam Treaty reinforces the existing provisions on the protection of human rights in the EU Treaty (articles 6 and 7), introducing a set of principles on which the Union is based ('liberty, democracy, respect for human rights and fundamental freedoms and the rule of law'), giving the CJEU powers to guarantee respect of these principles by the European institutions, and providing for sanctions in the event of a violation of the fundamental principles by a Member State.

A significant body of EU law defines positive action. Since 2000, the Charter of Fundamental Rights ${ }^{17}$ has been an essential element of European anti-discrimination law. The Charter embodies the principles of equality and non-discrimination and defines positive action measures. It sets out the principle of gender equality in all areas and positive action is provided for in this regard in article 23 of the Charter: 'Equality between men and women must be ensured in all areas, including employment, work and pay. The principle of equality shall not prevent the maintenance or adoption of measures providing for specific advantages in favour of the under-represented sex'. ${ }^{18}$

Article 157(4) TFEU prescribes the following:

With a view to ensuring full equality in practice between men and women in working life, the principle of equal treatment shall not prevent any Member State from maintaining or adopting measures providing for specific advantages in order to make it easier for the underrepresented sex to pursue a vocational activity or to prevent or compensate for disadvantages in professional careers.

The secondary law of the EU also recognises and defines positive action. Article 2(4) of Directive 76/207/EC'19 stipulates that 'this Directive

\footnotetext{
17 Charter of Fundamental Rights of the European Union [2000] OJ C364/1.

18 The adoption of the Charter was the result of a long-term process of implementing the CJEU's jurisprudence on the role that fundamental rights have in the European legal order. It had already found in 1969 that fundamental human rights were 'embedded in the general principles of Community law' and, as such, the Court itself provides protection. The protection of fundamental rights is left to the Court, which developed a list of rights, drawing inspiration from the general principles of Community law and the common constitutional traditions of the Member States.

19 Directive 76/207/EC on the implementation of the principle of equal treatment for men and women as regards access to employment, vocational training and promotion, and working conditions [1976] OJ L39/40.
} 
shall be without prejudice to measures to promote equal opportunity for men and women, in particular by removing existing inequalities which affect women's opportunities in the areas referred to in Article 1(1)'. Article 3 of the Recast Directive 2006/54/EC ${ }^{2020}$ on equal treatment for men and women in employment declares that 'Member States may maintain or adopt measures within the meaning of Article 141(4) of the Treaty with a view to ensuring full equality in practice between men and women in working life'.

With such an approach, the above-mentioned legislation provides enough space for the Member States to lay down specific measures in national legislation to give more opportunities to women who are in most cases under-represented in the workplace. Although EU legislation, guidelines, actions and funding possibilities have contributed to a certain degree of convergence, progress has been uneven in many respects:

In the countries with the highest unemployment rates, women's rate was even wider than men's rate: it reached $27.2 \%$ versus $18.9 \%$ for men in Greece, $20.7 \%$ versus $17.4 \%$ in Spain, $13.6 \%$ versus $12.5 \%$ in Cyprus, $12.2 \%$ versus $9.8 \%$ in Croatia, $12 \%$ versus $10.2 \%$ in Italy and $10.8 \%$ versus $10.5 \%$ in Portugal. ${ }^{21}$

Data on the gender pay gap are only available for 2015 and show that the pay gap stood at $16.3 \%$ in 2014 while in 2010 it was $16.4 \% .^{22}$ Data from October 2016 show that women still account for less than one in four $(23.9 \%)$ board members in the largest publicly listed companies registered in EU Member States. Indeed, there are only four countries France, Italy, Finland and Sweden, - where boards of large companies have at least $30 \%$ women. ${ }^{23}$

At the normative level, positive action measures fall within the scope of EU (the Marschall-Badec-Abrahamson doctrine) competences (articles 2 and 3(3) TEU, articles 8, 10, 19, 157(3), 157(4) and 352 TFEU, and article $23 \mathrm{CFREU})$. A significant number of States have incorporated a positive action provision similar to article 157(4) TFEU into their legal order and they have also extended its scope beyond employment. Member States complement their own legislation on gender equality in the light of the Directive on equal treatment $2002 / 73 / \mathrm{EC}^{24}$ and at the same time

20 Directive 2006/54/EC on the implementation of the principle of equal opportunities and equal treatment of men and women in matters of employment and occupation (recast) [2006] OJ L 204/23.

21 Commission, '2017 Report on Equality between Men and Women in the EU' (2017) 11.

22 ibid 20.

23 ibid 28.

24 Directive 2002/73/EC of the European Parliament and of the Council of 23 September 2002 amending Council Directive 76/207/EEC on the implementation of the principle of 
work on the transposition of the Racial Equality Directive and the Employment Equality Directive in their own legislation. In several cases, this has led to the adoption of comprehensive national laws covering discrimination on grounds of sex in parallel with the lessons learned from the foundations of discrimination. Apart from them (76/207/EC, 2002/73/ EC, 75/117/EC, 86/378/EC, 96/97/EC, 97/80/EC), there are several other directives relating to the principle of the application of equal treatment in the field of labour and employment, social security, protection of pregnancy and motherhood and the burden of proof. Article 7 of Directive 2000/78/EC defines positive action:

With a view to ensuring full equality in practice, the principle of equal treatment shall not prevent any Member State from maintaining or adopting specific measures to prevent or compensate for disadvantages linked to any of the grounds referred to in Article 1.

The recent Directive 2006/54/EC (Recast Directive) which covers these areas in a single legislative framework relates to the application of the principle of equal opportunities and the principle of equal treatment in employment and labour relations. Moreover, the Recast Directive shows that the positive action concept is very important in European law. The position of positive action is strengthened by tying article 3 of the Recast Directive with article 157(4) TFEU. Directive 2004/113 (Goods and Services $)^{25}$ also includes a positive action provision. Article 6 of the Goods and Services Directive states that 'with a view to ensuring full equality in practice between men and women, the principle of equal treatment shall not prevent any Member State from maintaining or adopting specific measures to prevent or compensate for disadvantages linked to sex'. The Race and General Framework Directives and the Gender Goods and Services Directive lay down that the principle of equal treatment 'shall not prevent' positive action measures. The Recast Directive states that 'Member States may maintain or adopt measures'.

Most Member States have introduced provisions on positive action in regulations that promote the principle of equal opportunities, but in practice different States and their national legal orders perceive positive action in different ways. ${ }^{26}$ However, there is an absence of women in decision-making institutions in the political arena, on management boards of public and private companies, and in education. For instance, only $3 \%$ of

equal treatment for men and women as regards access to employment, vocational training and promotion, and working conditions [2002] OJ L269/15.

25 Directive 2004/113/EC of 13 December 2004 implementing the principle of equal treatment between men and women in the access to and supply of goods and services [2004] OJ L $373 / 37$.

26 Selanec and Senden (n 13) 6. 
the largest publicly quoted companies have a woman chairing the highest decision-making body, ${ }^{27}$ although $60 \%$ of graduates are female. ${ }^{28}$ The underrepresentation of women in the leadership positions constitutes an untapped potential source of highly qualified human resources and evidenced by the discrepancy between the high number of female graduates and their absence from top-level positions'. ${ }^{29}$ Exclusion from the labour market obviously shows that European equality legislation needs positive action enforcement. Positive action measures can be used for different normative goals, e.g. to increase the number of the under-represented sex in politics and management boards, and to enable women and other disadvantaged groups to enter the labour market, education and other areas. In order to successfully implement positive action measures, Member States must put in place active implementation mechanisms. ${ }^{30}$

\section{Positive action on the CJEU's terrain}

EU positive action case law primarily concerns gender. Other grounds were added much later. The case law of the CJEU has gone from very restrictive to restrictive (at best). Interestingly, the CJEU adopts a pragmatic approach to sex equality rulings, and balances it from case to case. Therefore, the starting point for this analysis in this part of the paper is to consider how the Court ruled on positive action in the past and how these decisions reflect the development of gender equality legislation in favour of positive action enforcement. The authors will then try to answer whether the CJEU could consider the gender-balance directive a violation of the principle of equality between men and women.

The old article 2(4) of Directive 76/207 stipulates: 'This Directive shall be without prejudice to measures to promote equal opportunity for men and women, in particular by removing existing inequalities which affect women's opportunities in the areas referred to in Article 1(1)'. The CJEU's case law relating to article 2(4) of the above-mentioned Directives includes: Commission v France; Kalanke v Freie Hansestadt Bremen; Marschall $v$ Land Nordrhein-Westfalen; Badeck $v$ Landesan beim Staatsgerichtshof des Landes Hessen; Abrahamsson v Fogelqvist; Lommers $v$ Minister Van Landbouw, Natuurbeheer en Visserij; Briheche; Von Colson and Kamman. These cases will be briefly considered below.

27 Commission, 'Women and Men in Leadership Positions in the European Union, 2013 (2013) <http://ec.europa.eu/justice/gender-equality/files/gender_balance_decision_making/131011_women_men_leadership_en.pdf> accessed 3 January 2018

28 Commission (n 5).

29 ibid 19.

30 ibid 23. 
The first CJEU judgement on positive action was not so 'positive' for women. In 1988, in Commission v France, ${ }^{31}$ the Court had the first chance to interpret the gender 'positive action' clause of the then Directive 76/207/EEC on Equal Treatment for Men and Women. ${ }^{32}$ The Court concluded that:

The exception provided for in [the positive action clause of the Directive] is specifically and exclusively designed to allow measures which, although discriminatory in appearance, are in fact intended to eliminate or reduce actual instances of inequality which may exist in the reality of social life. Nothing in the papers of the case, however, makes it possible to conclude that a generalized preservation of special rights for women in collective agreements may correspond to the situation envisaged in that provision. ${ }^{33}$

By starting the saga on 'no to automatic preferences for women', in the controversial Kalanke ${ }^{34}$ ruling, the CJEU stated that 'national laws which guarantee women absolute and unconditional priority for appointments or promotion in sectors in which they are under-represented go beyond the limits of the exception provided by art 2(4)'. Advocate General Tesauro, in his opinion in Kalanke, interprets gender-specific measures necessary to achieve real and effective substantive equality (not as a 'genuine derogation' from the principle of equal treatment). ${ }^{35}$ Actually, Tesauro emphasised that article 2(4) of Directive 76/207 addressed equality of opportunities, not outcomes. However, the CJEU left unanswered what equality of opportunity is and how 'proportional' a sex-related preference must be. In Kalanke, the CJEU decided in abstracto, leaving the final decision to the national court which applies the law to the facts of the case. Interestingly, reaction to this case (no to 'automatic preferences') provoked a change in 1997 to the founding treaties in order to impose 'positive action' measures in favour of women. Later, the CJEU accepted certain preferences in favour of women, but still under rather strict conditions.

A month after the Amsterdam Treaty was signed, but before its entry into force in 1999, the Court started to refine and develop its case

\footnotetext{
31 Case C-312/86 Commission v France ECLI:EU:C:1988:485.

32 Council Directive 76/207/EEC of 1976 on the implementation of the principle of equal treatment for men and women as regards access to employment, vocational training and promotion, and working conditions [1976] OJ L39/40. In 2006, this Directive was replaced by Directive 2006/54/EC on equal treatment of men and women in matters of employment and occupation (recast) [2006] OJ L204/23.

33 Commission $v$ France (n 31) paras 14 and 15.

34 Case C-450/93, Eckhard Kalanke v Freie Hansestadt Bremen ECLI:EU:C:1995:322.

35 Case C-450/93 Eckhard Kalanke v Freie Hansestadt Bremen ECLI:EU:C:1995:105, Opinion of AG Tesauro, para 15.
} 
law on positive action - without ever acknowledging any influence of the new Treaty provision. Namely, the CJEU still refers to positive action as a derogation from the principle of equality, not as a rule having the objective of 'ensuring full equality in practice' as it is mentioned in the new Treaty provision on positive action. Gradually, the clear rule spelled out in Kalanke became more flexible, even if it was not completely abandoned. In November 1997 in its Marschall ${ }^{36}$ ruling, the CJEU confirmed there was no automatic preference in cases of the under-represented sex but it softened its position (yes, but provided certain circumstances were fulfilled) by ruling:

A national rule which, in a case where there are fewer women than men at the level of the relevant post in a sector of the public service and both female and male candidates for the post are equally qualified in terms of their suitability, competence and professional performance, requires that priority be given to the promotion of female candidates unless reasons specific to an individual male candidate tilt the balance in his favour is not precluded by Article 2(1) and (4) of Council Directive 76/207/EEC of 9 February 1976 provided that: $a$. In each individual case the rule provides for male candidates who are equally as qualified as the female candidates a guarantee that the candidatures will be the subject of an objective assessment which will take account of all criteria specific to the candidates and will override the priority accorded to female candidates where one or more of those criteria tilts the balance in favour of the male candidate, and $b$. Such criteria are not such as to discriminate against the female candidates.

Although in Marschall and Kalanke the facts were almost identical, in Marschall the CJEU overturned the result of its decision in Kalanke without overruling it.

In Badeck, ${ }^{37}$ the CJEU reinforced the less restrictive approach and confirmed and developed its decision in Marschall, and it was quite clear that a positive action measure in favour of women was compatible with EU law where it does not unconditionally and automatically give priority to women and where candidatures are the subject of objective assessment, which takes account of the specific personal situation of all candidates. The CJEU's argumentation also widened the scope of the applicability of positive action measures. ${ }^{38}$ However, it remains unclear what counts as qualifications and who defines the qualifications.

\footnotetext{
36 Case C-409/95 Hellmut Marschall v Land Nordrhein-Westfalen ECLI:EU:C:1997:533.

37 Case C-158/97 Georg Badeck and Others ECLI:EU:C:2000:163.

38 NE Ramos Martin, 'Positive Action in EU Gender Equality Law: Promoting Women in Corporate Decision-Making Positions' (2014) 3(1) Spanish Labour Law and Employment Relations Journal 20, 28.
} 
In Abrahamsson, ${ }^{39}$ the CJEU stated that article 2(1) and (4) and article 141(4) EC preclude

national legislation under which a candidate for a public post who belongs to the under-represented sex and possesses sufficient qualifications for that post must be chosen in preference to a candidate of the opposite sex who would otherwise have been appointed, where this is necessary to secure the appointment of a candidate of the under-represented sex and the difference between the respective merits of the candidates is not so great as to give rise to a breach of the requirement of objectivity in making appointments.

Both Marschall and Abrahamsson CJEU clearly emphasised that national legislation providing for positive action to counter women's disadvantages in professional posts is only in line with the equal treatment principle if the criterion of equal qualifications is met.

In Lommers, ${ }^{40}$ the CJEU gave new light to the interpretation of positive action measures and held that derogations from the equal treatment principle must be interpreted 'proportionately' (as opposed to 'restrictively' as in its ruling in Kalanke).

In Briheche, ${ }^{41}$ the CJEU extended the scope for lawful positive action. Article 3(1) and article 2(4) must be interpreted as meaning that

\footnotetext{
39 'Article 2(1) and (4) of Directive 76/207 and Article 141(4) EC also preclude national legislation of that kind where it applies only to procedures for filling a predetermined number of posts or to posts created as part of a specific programme of a particular higher educational institution allowing the application of positive discrimination measures. Art 2(1) and (4) of Directive $76 / 207$ does not preclude a rule of national case law under which a candidate belonging to the under-represented sex may be granted preference over a competitor of the opposite sex, provided that the candidates possess equivalent or substantially equivalent merits, where the candidatures are subjected to an objective assessment which takes account of the specific personal situations of all the candidates. The question whether national rules providing for positive discrimination in the making of appointments in higher education are lawful cannot depend on the level of the post to be filled.' Case C-407/98 Katarina Abrahamsson and Leif Anderson v Elisabet Fogelquist ECLI:EU:C:2000:367.

40 'Article 2(1) and (4) does not preclude a scheme set up by a Minister to tackle extensive under-representation of women within his Ministry under which, in a context characterised by a proven insufficiency of proper, affordable care facilities, a limited number of subsidised nursery places made available by the Ministry to its staff is reserved for female officials alone whilst male officials may have access to them only in cases of emergency, to be determined by the employer. That is so, however, only in so far, in particular, as the said exception in favour of male officials is construed as allowing those of them who take care of their children by themselves to have access to that nursery places scheme on the same conditions as female officials.' Case C-476/99 H Lommers $v$ Minister van Landbouw, Natuurbeheer en Visserij ECLI:EU:C:2002:183.

41 'As the Commission has correctly pointed out, such a provision automatically and unconditionally gives priority to the candidatures of certain categories of women, including widows who have not remarried who are obliged to work, reserving to them the benefit of the exemption from the age limit for obtaining access to public - sector employment and excluding widowers who have not remarried who are in the same situation' (para 27). Case C-319/03 Serge Briheche $v$ Ministre de l'Intérieur, Ministre de l'Éducation nationale and Ministre de la Justice ECLI:EU:C:2004:398.
} 
they preclude a national provision, such as that in question in the main proceedings, which reserves the exemption from the age limit for obtaining access to public sector employment to widows who have not remarried and who are obliged to work, excluding widowers who have not remarried who are in the same situation.

The CJEU has also developed criteria to assess the legality of positive action measures: they must be based on clear unambiguous criteria, address specific career inequalities and help the under-represented sex to conduct their life on a more equal footing with the other sex. The Commission's factsheet outlines the requirements stated in the case law:

1) The measures must concern a sector in which women are underrepresented (Kalanke case, C-450/93); 2) They can only give priority to equally qualified female candidates over male candidates (Abrahamsson case, C-407-98); 3) They must not give automatic and unconditional priority to equally qualified candidates of the under-represented sex, but must include the possibility of granting exceptions in justified cases which take into account the individual situation, notably the personal situation of each candidate (Marschall case, C-409/95). ${ }^{42}$

O'Cinneide claims that:

This case-law thus continues to cause some difficulties. The CJEU has not yet clarified what exactly constitutes giving automatic preference to women. This means that the position of the CJEU on positive action remains ambiguous and uncertain. This lack of clarity may at times discourage the use of certain forms of positive action in Member States, as governments can be reluctant to risk a negative decision by the CJEU. ${ }^{43}$

It is difficult to foresee whether the CJEU will adopt similar legal reasoning to positive action for other grounds of discrimination or positive action in areas beyond employment. As Caruso claims:

a close analysis of the CJEU's decisions on positive action in favour of women casts serious doubt on the wisdom of extending that court's equality paradigm to matters of race, ethnicity, or religion ... [A]nchored as it is to a rigidly individualistic conception of rights, the Court lacks both conceptual and institutional tools to embrace complex issues of collective justice in diverse societies. ${ }^{44}$

42 Commission (n 3) (emphasis in the original).

43 C O'Cinneide, 'Positive Action' (2014) ERA, Academy of European Law 18.

44 D Caruso, 'Limits of the Classic Method: Positive Action in the European Union after the New Equality Directives' (2003) Boston University School of Law Working Paper Series, Public Law \& Legal Theory, Working Paper No 03-21, 3. 
Advocating for a better doctrinal model for judicial evaluation of positive action might be a logical step forward but might also be too ambitious. In the application of positive action at national level, there is a need for intensive dialogue between the CJEU and national courts. Implementation of sex equality legislation requires appropriate and effective sanctions. In its Von Colson and Kamman ruling, ${ }^{45}$ the CJEU concludes the following:

although Directive No 76/207/EEC, for the purpose of imposing sanctions for the breach of the prohibition of discrimination, leaves the Member States free to choose between the different solutions suitable for achieving its objective, it nevertheless requires that if a Member State chooses to penalise breaches of that prohibition by the award of compensation, then in order to ensure that it is effective and that it has a deterrent effect, that compensation must in any event be adequate in relation to the damage sustained and must therefore amount to more than purely nominal compensation such as, for instance, the reimbursement only of the expenses incurred in connection with the application. It is for the national court to interpret and apply the legislation adopted for the implementation of the directive in conformity with the requirements of community law, in so far as it is given discretion to do so under national law.

\section{Proposal: the first crack in the glass ceiling?}

The European Commission proposed the Directive of the European Parliament and of the Council on improving the gender balance among non-executive directors of companies listed on stock exchanges and related measures on 14 November 2012. 'On November $20^{\text {th }}, 2013$, the proposal passed through the first reading in the European Parliament'. ${ }^{46}$ Afterwards, the Economic and Social Committee and Committee of Regions discussed the proposal, and it was adopted by the European Parliament at its first reading. ${ }^{47}$ The next step was for the directive to be adopted by the Council at the first reading, as part of the legislative procedure. ${ }^{48}$ However, the voting process in the Council took some time, as the Council did not agree with the first reading of the Parliament. Member States have had opposing opinions on the proposal, mostly due to the principle

\footnotetext{
45 Case C-14/83 Von Colson and Kamman ECLI:EU:C:1984:153, para 22.

46 The Women-on-Boards Directive in the Council' (EWSDGE, 16 December 2014) <www. ewsdge.eu/the-women-on-boards-directive-in-the-council/> accessed 3 January 2018.

47 European Parliament, 'Gender Balance on Boards' (Legislative Train Schedule, Area of Justice and Fundamental Rights) <www.europarl.europa.eu/legislative-train/theme-areaof-justice-and-fundamental-rights/file-gender-balance-on-boards> accessed 3 January 2018.

48 Treaty on the Functioning of the European Union (n 11).
} 
of subsidiarity. On 11 December 2014, the Proposal for the Women on Company Boards Directive was discussed. According to an official press release, the Council 'was not able to reach a general approach'. One year later, in December 2014, the Council rejected the proposal. It explained the rejection by reason of not reaching an agreement. In the final decision, it invited the preparatory bodies to 'fix' the file and continue work on it to try to find a compromise. After significant time spent on finalising the proposal, a progress report was filed on 11 June 2015 in which it was explained that the problem would remain unsolved because there was no consensus about the regulation. Some Member States preferred national or non-binding measures, and some preferred EU legislation. Therefore, the proposal has been halted until today due to a lack of political will, although it seems there was overall support for the 'adoption of the 2012 proposal for a Directive on improving the gender balance among nonexecutive directors of companies listed on stock exchanges by $2016{ }^{\prime}{ }^{49}$

The problem of boards with a gender imbalance clearly exists and it needs to be fixed by a binding, stable form of legislation, because the population of women has always been under-represented there. ${ }^{50}$ Progress in increasing the presence of women on company boards has been very slow, with an average annual increase in the past few years of just 0.6 percentage points per year. ${ }^{51}$ 'Company boards in the EU are characterised by persistent gender imbalances, as evidenced by the fact that only $13.7 \%$ of corporate seats in the largest listed companies are currently held by women (15\% among non-executive directors)'. With this in mind, it is clear why the Commission tried to encourage 'the private sector to increase the presence of women at all levels of decision-making, notably by positive action programmes, and called upon the Commission to take steps to achieve balanced gender participation in this regard'. Trends in national legislation such as quotas were also used as an example which led to the proposal itself. ${ }^{52}$ The European Commission proposed the Directive of the European Parliament and of the Council on improving the gender balance among non-executive directors of companies listed on stock exchanges and related measures on 14 November 2012.

\footnotetext{
49 European Commission, 'Strategic Engagement for Gender Equality 2016-2019' (Directorate-General for Justice and Consumers 2015).

50 Z Krečkova 'Women on Boards: The Perspective of Czech and Slovak Republics within the European Context' (2013) 1 (1) Management: Science and Education 40 <www.infoma. fri.uniza.sk/archive/mse/v2n1/040-042.pdf> accessed 3 January 2018.

51 V Reding, Vice-President of the European Commission, EU Justice Commissioner 'Mapping EU Action on Gender Equality: From the Treaty of Rome to Quotas' (speech to Harvard Club Belgium/Brussels, 8 October 2012).

52 O Alvaro and M Gondek, 'Women on Company Boards: An Example of Positive Action in Europe' (2014) Robert Schuman Centre for Advanced Studies Research Paper No RSCAS 2014/34 <http://cadmus.eui.eu/bitstream/handle/1814/32251/RSCAS\%202014_34 pdf?sequence> accessed 3 January 2018.
} 
The ratio of this proposal was the attempt to exert direct influence on this area of interest: 'Member States and the EU institutions have undertaken numerous efforts during several decades to promote gender equality in economic decision-making, notably to enhance female presence in company boards, by adopting recommendations and encouraging self-regulation'. ${ }^{53}$ Finally, 'with this proposal, the European Commission is answering the strong call of the European Parliament for EU action to bring about gender equality in corporate boardrooms. Today, we are asking large listed companies across Europe to show that they are serious when it comes to gender equality in economic decision-making. ${ }^{54}$ The proposal itself states that it 'seeks to promote gender equality in economic decision-making and to fully exploit the existing talent pool of candidates for more equal gender representation on company boards, thereby contributing to the Europe 2020 objectives. The proposed directive will lead to breaking down the barriers that women face when aiming for board positions and to improved corporate governance, as well as enhanced company performance'.

Admitting the problem of the higher amount of men in corporate boards and not being able to solve it within the existing framework, the European Commission proposed the directive whose 'goal is 30\% women on the boards of the major European companies in 2015 and $40 \%$ by 2020'. The substantive target of the proposal is elaborated in article 4, and that is that Member States either 'aim to attain, by 31 December 2020, the objective that members of the under-represented sex hold at least $40 \%$ of non-executive director positions' or 'aim to attain, by $31 \mathrm{De}$ cember 2020, the objective that members of the under-represented sex hold at least $33 \%$ of all director positions, including both executive and non-executive directors'. What is more, it will aim at 'publicly listed companies, due to their economic importance and high visibility'. 'It is in the interests of the business community and society as a whole for the governance practices of publicly listed companies to be transparent'. ${ }^{55}$ Consequently, 'they set standards for the private sector at large. Moreover, they tend to have larger boards and have a similar legal status across the EU, providing the necessary comparability of situations'. ${ }^{56}$ The purpose

\footnotetext{
53 G Mike, 'Gender Balance or Imbalance More Women on Company Boards?' (2013) 9(4) Iustum Aequum Salutare < http://ias.jak.ppke.hu/hir/ias/20134sz/15.pdf> accessed 3 January 2018.

54 José Manuel Barroso, President of the European Commission, as cited in Commission, 'Women on Boards: Commission Proposes 40\% Objective' (Press Release, 14 November 2012).

55 European Women on Boards, 'New Study: Progress and Challenges for Women on Company Boards' (Press Release, 27 April 2016) <https://t.co/7CiWDmsqWO> accessed 3 January 2018.

56 Mike (n 53).
} 
of the proposal was to tackle the most important issues regarding gender equality, and it tried to set realistic targets. This directive was meant to help achieve gender-balanced boards and to bring down the barriers which caused the glass ceiling. The choice of options was left to the Member States to adjust the detailed regulation to their specific situations in terms of national company law and to choose the most appropriate means of enforcement and sanctions. It also allows individual Member States to go beyond the minimum standard, on a voluntary basis'. ${ }^{57}$

Apart from the quotas, Member States have to fulfil other obligations. Firstly, Member States have to set individual quantitative gender balance objectives in areas where general regulations do not apply directly.

Besides this, the proposal established the duty of reporting in which public listed companies have the obligation to report to national equality bodies. Listed companies are required to provide information on the gender composition of their boards to competent national authorities. This information should be published on the company's website and, if the company in question does not meet the objective, it should include a description of measures the company has taken so far and intends to take to meet the objective in the future.

The duty to inform also includes the duty to inform candidates for election or appointment:

While respecting the provisions of Directive 95/46/EC, Member States shall ensure that, in response to a request from a candidate who has been considered in the selection for appointment or election, listed companies are obliged to inform that candidate of the following: (a) the qualification criteria upon which the selection was based, (b) the objective comparative assessment of the candidates under those criteria, and, (c) where relevant, the considerations tilting the balance in favour of a candidate of the other sex. ${ }^{58}$

Furthermore, dealing with requests from candidates, all decisive parameters (qualification, objective comparison and considerations crucial for equality) need to be explained to candidates in a transparent way:

\footnotetext{
57 R Somssich, 'Sources of the EU Law and Decision Making Institutional Framework in the EU' (Presentation at the Workshop on the Transposition of EU Legislation into the Legal System of Turkey, Ankara, 25 May 2016) < www.slideshare.net/SIGMA2013/rekasomssich-sources-of-the-eu-law-and-decision-making-institutional-framework-in-the-euankara-25-may-2016> accessed 3 January 2018.

58 Council of the European Union, Report on the Proposal for a Directive of the European Parliament and of the Council on improving the gender balance among directors of companies listed on stock exchanges and related measures 16300 (2014) art 4a, para 3

<http: / / register.consilium.europa.eu/doc/srv?l=EN\&f=ST\%2016300\%202014\%20INIT> accessed 17 January 2018.
} 
In the selection of candidates for appointment or election to the positions referred to in Article 4(1), Member States shall ensure that, when choosing between candidates who are equally qualified in terms of suitability, competence and professional performance, priority shall be given to the candidate of the under-represented sex, unless an objective assessment taking account of all criteria specific to the individual candidates tilts the balance in favour of the candidate of the other sex. ${ }^{59}$

If the candidate of the under-represented sex affirms a prima facie instance of discrimination, the burden of proof will shift to the respondent company.

In addition, a new procedural obligation switches the burden of proof on listed companies in the case of the non-employment of a candidate of the under-represented sex, which has to be incorporated in judicial systems of all Member States:

Member States shall take the necessary measures, in accordance with their national judicial systems, to ensure that where a candidate of the under-represented sex establishes facts from which it may be presumed that he or she was equally qualified as compares with the candidate of the other sex selected for appointment or election, it shall be for the listed company to prove that there has been no breach of Article $4 a(2) .{ }^{60}$

As far as sanctions go, they can be considered as a weak instrument for the fulfilment of the obligations set by the directive. Sanctions are of three main types: annual reports, procedural requirements, and individual quantitative objectives. Companies should report annually on the progress made. The main criterion for a position on the board should be qualifications, on account of the obligation to set objective criteria of qualifications in order to prevent promotion that is mainly based on sex. According to the CJEU case law on positive action, preference is given to a member of the under-represented sex who has equal qualifications if the objective criteria do not go in favour of the other candidate.

Nevertheless, non-compliance with the directive is not penalised. 'This Article obliges Member States to lay down rules on sanctions applicable in case of breach of this Directive. These sanctions must be effective, proportionate and dissuasive. A non-exhaustive list of possible concrete measures is set out'. ${ }^{61}$ The only 'sanction' is the obligation of companies to explain the reasons for not meeting the criteria and a description of the

\footnotetext{
Council (n 58) art 4a, para 2.

60 Council (n 58) art 4a, para 3.

61 Commission (n 12).
} 
measures which have already been taken or an outline of the plans to take them. ${ }^{62}$

Considering the existing sanctions, more severe enforcement measures could be imposed respecting the limits of proportionality, which does not let failure to respect the numerical goals go unpunished. Punishment should be in the form of fiscal incentives or penalties under the area of public procurement. These types of sanctions would have great economic effects on publicly listed companies, as they are led by profit and economic reasoning. One of the aims of the proposal is assuredly the flexibility clause. Contrary to its purpose, allowing the more proactive Member States to develop their own policy to promote equality programmes without clashing with the substance of the proposal permits very wide interpretation in national legislation and makes room for tailormade gender-diversity strategies. Although subsidiarity is very important in EU law, it should not affect the efficiency of the provision as in this case. However, due to subsidiarity and weak sanctions, this proposal was not implemented and even if it had been it would have had quite a weak impact on gender equality on boards due to the weak enforcement instruments it imposes.

An interesting aspect of this directive is also the ability of Member States to exert their discretion, because certain MSs which have already made positive measures to ensure more balanced representation of both sexes among the directors of listed companies following the objectives set out in article 4(1), or have progressed not far from the objectives, can decide to suspend the application of article $4 \mathrm{a}$. If they decide to use their right to do so, the objectives set out in article 4(1) will be considered to be fulfilled.

After analysing the obligations laid down by the proposal and the lack of sanctions, it is quite clear that enforcement measures have to be introduced. Firstly, Member States have to come up with rules on enforcement measures which can be applied to infringements of the national provisions adopted pursuant to articles 4 and 5 of the directive as applicable and must take all necessary measures to ensure that they are applied. Secondly, the enforcement measures have to be effective, proportionate and dissuasive. Finally, listed companies can be held liable only for the acts which may be connected to them by national law.

Due to its obligation and sanctions, this directive was often criticised because it does not impose an obligation to guarantee a certain result, but an obligation to put in one's best efforts to take the necessary measures

62 European Women Shareholders Demand Gender Equality, 'The Women-on-Boards Directive in the Council' (16 December 2014) <www.ewsdge.eu/the-women-on-boards-directive-in-the-council/> accessed 3 January 2018. 
that can contribute to achieving the objective'. ${ }^{63}$ It was also criticised because of its economic, and not altruistic, motives. ${ }^{64}$ On the one hand, this directive 'does not constitute an appropriate legal solution for this problem' because of the lack of sanctions and weak obligations. On the other hand, it is unanimously held that 'failing to reach agreement on the proposal would mean missing an opportunity to achieve any progress at all in the near future in a significant number of Member States'. ${ }^{65}$

Another question which must be asked related to this directive is if it goes far enough. The proposal addresses the serious problem of women's under-representation in economic decision-making positions, setting a goal of a $40 \%$ threshold of women among non-executive directors/supervisory board members by 2020 for private listed companies. The proposal for the directive 'seeks to achieve a more balanced representation of men and women among the directors of listed companies by establishing measures aimed at accelerated progress'. Why 40\%?

The proposed objective of $40 \%$ for the minimum share of both sexes is in line with the targets currently under discussion and set out in several EU Member States/EEA countries. This figure is situated between the minimum of the 'critical mass' of 30\%, which has been found necessary to have a sustainable impact on board performance and full gender parity (50\%). ${ }^{66}$

Why only non-executive boards?

Non-executive or supervisory directors are recruited by companies for a variety of purposes. Of particular importance is their role in overseeing executive or managing directors and dealing with situations involving conflicts of interests. It is vital to foster that role in order to restore confidence in financial markets. Member States should therefore be invited to adopt measures which would be applicable to listed companies, defined as companies whose securities are admitted to trading on a regulated market in the Community. ${ }^{67}$

\footnotetext{
63 L Senden and M Visser, 'Balancing a Tightrope: The EU Directive on Improving the Gender Balance among Non-executive Directors of Boards of Listed Companies' (2013) 1 European Gender Equality Law Review

<http://dspace.library.uu.nl/bitstream/handle/1874/287052/Senden+-+Balancing+a+ Tightrope+-+The+EU+Directive.pdf?sequence=1>accessed 3 January 2018.

64 M Szydło, 'Constitutional Values Underlying Gender Equality on the Boards of Companies: How Should the EU Put These Values into Practice?' (2014) 63(1) International and Comparative Law Quarterly

<www.cambridge.org/core/services/aop-cambridge-core/content/view S002058931300050X> accessed 3 January 2018.

65 Senden and Visser (n 64).

66 Commission (n 12) (Purpose of the proposal).

67 Commission, Recommendation of 15 February 2005 on the role of non-executive or supervisory directors of listed companies and on the committees of the (supervisory) board [2005) ] OJ L 52/51
} 
The main goal is to promote gender-diversity in companies' boards, and with that gender-diversity in decision-making, and thus enabling women to participate:

Minimum harmonization as regards both a requirement for listed companies to take appointment decisions on the basis of an objective comparative assessment of the qualifications of candidates and the setting of a quantitative objective for the gender balance among non-executives directors seems essential to ensure a competitive playing field and to avoid practical complications for listed companies in the internal market. ${ }^{68}$

The proposal has quite a restricted scope of application, because it targets publicly listed companies which have their registered office in one of the Member States and excludes small and medium-sized enterprises. Moreover, publicly listed companies usually have larger boards and a similar legal status and way of functioning across the EU, providing for necessary similarity between situations. Small and medium-sized enterprises with fewer than 250 employees and an annual profit that does not exceed EUR 50 million are excluded from the scope even if they are publicly listed. ${ }^{69}$ The proposal can be applied only to publicly listed and EU-registered companies in the European Union. There are 7,500 such companies in the EU, 2,500 of which are SMEs. ${ }^{70}$ Consequently, this means that the legislative proposal is likely to affect a total of about 5,000 companies. Consequently, it is quite clear that the proposal does not go far enough. Taking the weak obligations and even weaker sanctions, and the flexibility and discretion of Member States into consideration, it is clear that from a formal/procedural point of view it fails to set a positive example for gender-balanced boards.

Analysing the subjects of its measures, the directive cannot be treated as a positive measure and a revolution in economic decision-making for the under-represented sex. For all these reasons, the nature of the directive also becomes quite fragile. Can it be considered hard law taking into account its various weak impacts given the non-binding form of the proposed positive action? On the one hand, the legislative procedure behind the directive, alongside the direct effect that it has on the Member States, can make it seem a hard law instrument. On the other hand, with the sunset clause, the discretion of Member States and its weak sanctions

68 Commission (n 12) Policy context.

69 Commission, 'The New SME Definition: User Guide and Model Declaration' (Enterprise and Industry Publications) <www.eusmecentre.org.cn/sites/default/files/files/news/ SME\%20Definition.pdf> accessed 3 January 2018.

70 Commission, 'Gender Balance on Boards (National Factsheet - Country: United Kingdom, 2013) <http://ec.europa.eu/justice/gender-equality/files/womenonboards/womenonboards-factsheet-uk_en.pdf> accessed 3 January 2018. 
and obligations, the proposal can be treated as a soft law instrument, which would explain the indifference of the EU towards this directive.

Nevertheless, considering the rich history of CJEU case law and the legislative background that forms the legal base for the directive, it is noticeable that the directive is the only solution for gender-balanced boards. In the scope of legal standards incorporated in the case law, it is clear that the directive comes as a result of them and that it fulfils the requirements of the CJEU case law. It is especially obvious in one of proposals' obligation, where the legislative influence of the EU was broadened by allowing the Member States to make their own objective criteria for the under-represented sex. This idea was based on the Kalanke case, where the Court said that 'national laws which guarantee women absolute and unconditional priority for appointments or promotion in sectors in which they are under-represented go beyond the limits of the exception provided by art 2(4)'. Furthermore, another obligation in the directive is to give priority to the candidate of the under-represented sex, unless some crucial objective criteria specific to the individuals go in favour of the other candidates, which is the result of the Courts' opinion in Marschall:

A national rule which, in a case where there are fewer women than men at the level of the relevant post in a sector of the public service and both female and male candidates for the post are equally qualified in terms of their suitability, competence and professional performance, requires that priority be given to the promotion of female candidates unless reasons specific to an individual male candidate tilt the balance in his favour is not precluded..$^{71}$

Further, the directive sets rules which predict objective standards as criteria for the under-represented sex in comparative situations, as stated by the CJEU in Badeck:

in sectors of the public service where women are under-represented, [priority is given], where male and female candidates have equal qualifications, to female candidates where that proves necessary for ensuring compliance with the objectives of the women's advancement plan, if no reasons of greater legal weight are opposed, provided that that rule guarantees that candidatures are the subject of an objective assessment which takes account of the specific personal situations of all candidates. ${ }^{72}$

The directive also confirms the Courts' opinion in Abrahamsson by favouring the candidates of the under-represented sex where there are not so many objective differences between candidates:

\footnotetext{
${ }_{71}$ Marschall (n 36).

72 Badeck (n 37).
} 
national legislation under which a candidate for a public post who belongs to the under-represented sex and possesses sufficient qualifications for that post must be chosen in preference to a candidate of the opposite sex who would otherwise have been appointed, where this is necessary to secure the appointment of a candidate of the under-represented sex and the difference between the respective merits of the candidates is not so great as to give rise to a breach of the requirement of objectivity in making appointments. ${ }^{73}$

Thus, it is clear that the directive follows the goals of positive action measures and is therefore a vital source of law for gender equality in corporate boards.

Despite the obvious resemblance of the directive to the already presented legal standards in the scope of CJEU case law, the question arises whether the CJEU itself could consider the directive as a violation of the principle of equality between men and women:

According to Community case law, both the principle of equality and the prohibition of discrimination require that, save where there is an objective justification, comparable situations must not be treated differently, and different situations must not be treated in the same way. ${ }^{74}$

The CJEU could consider the directive a violation of the principle of equality between men and women, due to its different treatment of comparable situations. The principle of equality is directly linked to the prohibition of discrimination and the different treatment of the same situations. It is considered that all groups are treated equally, but in situations where this is not the case, the CJEU can test the compatibility of the provision (in this case the Women on Boards Directive) with the principles of the EU (in this case, the principle of equality). Moreover, if the CJEU compares the rules set by the directive through the proportionality test, it might be established that there is an objective justification for candidates not to be treated in the same way (why priority is given to the under-represented sex) and there must be a comparable situation (the same work experience, education, etc) to remain outside the domain of discrimination based on sex. Another factor that speaks in favour of the directive and its compatibility with the principle of equality in the scope of EU law is the fact that the directive is a positive action measure set by the EU, and by its very nature it aims to give preference

73 Case C-407/98 Katarina Abrahamsson and Leif Anderson $v$ Elisabet Fogelquist ECLI:EU:C:2000:367.

$74 \mathrm{C}$ McCrudden and S Prechal, 'The Concepts of Equality and Non-Discrimination in Europe: A Practical Approach' (European Commission, European Network of Legal Experts in the Field of Gender Equality, 2009). 
to a certain under-represented group by setting hard quotas to ensure equal participation. Thus, the directive cannot be treated as a violation of the principle of equality despite different treatment of subjects in a comparable situation due to its justification (by applying the proportionality test) and its nature (a new step of EU positive action).

However, the voting process in the Council will take some time, as the Council will most probably not agree with the first reading of the Parliament. EU Member States have different conflicting views regarding the proposal for the directive. Some Member States criticise the proposal for not complying with the principle of subsidiarity. In an attempt to reach a compromise between the Member States, the Italian presidency of the Council introduced a broad flexibility clause (article 4b) and extended the deadlines for implementation and reporting (articles 5, 8 and 9). Nevertheless, it seems that not all is lost. According to recent information, 'EU Commissioner Jourová outlines her position on gender quotas and the business case for more women on boards. She has given a strong hint that the EU Directive is still on the table. She called on businesses to take action even though the directive is 'pending'. ${ }^{75}$ Thus, perhaps it is still possible for the EU to provide a unified source of law to regulate and create gender-balanced boards.

\section{Conclusion}

This paper has analysed through critical lenses the existing concept of positive action. The EU gender equality legislation is rich but lacks a comprehensive legislative framework to improve the participation of women in decision-making structures. At the level of Member States, there is lack of monitoring mechanisms of positive action implementation. This has led to positive action never achieving the results of substantive equality. Drawing on an analysis of the CJEU's case law on equality between men and women, it has been necessary for certain concepts defined by equality directives to be crystallised in practice. Positive action is a concept which looks perfect on paper but has never been completely implemented in practice. The problem with positive measures is the selective use of criteria which may ultimately produce even more inequalities. There is also a need to provide clear guidelines to promote positive action. Interestingly, the CJEU's case law does not lead to the clarifying circumstances necessary for the application of positive action. For instance, the CJEU has not yet clarified what exactly constitutes giving automatic preference to women. This means that the position of the

\footnotetext{
75 'Commissioner Jourová - Women on Boards Directive "Pending”' (Equality Strategies, 7 September 2016) <www.equalitystrategies.ie/blog/2016/09/07/commissioner-jourovawomen-on-boards-directive-pen/> accessed 3 January 2018.
} 
CJEU on positive action remains ambiguous and uncertain. How far the national courts have actually implemented the 'guidelines' put in practice by the CJEU is an area that is generally inadequately investigated.

The proposal for the directive is a form of positive measures lying within the scope of EU competences supported by a rich legal base. The ratio of this proposal was an attempt to exert direct influence on the under-representation of women on boards. The directive itself sets the goals in the form of quotas (ie 30\% women on boards in 2015 and $40 \%$ by 2020) which would affect large public listed companies. It has imposed many obligations (the duty of reporting, the duty to inform candidates for election or appointment, priority given to a candidate of the underrepresented sex, shifting the burden of proof) which go alongside the rich CJEU case-law standards and requirements. The proposal has weak sanctions, such as annual reports, procedural requirements, and individual quantitative objectives. More severe enforcement measures could be imposed respecting the limits of proportionality, for example fiscal incentives or penalties under the area of public procurement. This has also raised many questions and controversies about the hard or soft law nature of the directive.

However, the directive can still be considered a hard law instrument due to the legislative procedure behind the directive, alongside the direct effect that it has on the Member States. The directive is also quite fragile, but considering the rich history of CJEU case law and the legislative background that forms its legal base, it can be seen that the directive is the only solution for gender-balanced boards. In the scope of legal standards incorporated in the case law, it is clear that the directive comes as a result of them and that it fulfils the requirements of the CJEU case law. Taking all this into account, the directive would be a perfect form of positive action to tackle the specific issue of gender-balanced boards and to make equality effective. 